ISSN 0206-5657. Вісник Львівського університету. Серія біологічна. 2018 Випуск 78. С. 66-69 Visnyk of the Lviv University. Series Biology. 2018. Issue 78. P. 66-69

УДК 582.35/.99(477)

\title{
ON THE HERBARIUM COLLECTION OF POPULATIONS OF FESTUCA L. SPECIES (POACEAE) (LWKS)
}

\author{
I. Bednarska \\ Institute of Ecology of the Carpathians, NAS of Ukraine \\ 4, Kozelnytska St., Lviv 79026, Ukraine \\ e-mail:Ibednarska@ukr.net
}

As a result of monographic studies of taxonomy of the genus Festuca in the flora of Central Europe, a specialized herbarium collection of the genus was established on the base of LWKS. The key peculiarity of the collection is the populational approach to the material. As of today, about 600 population sample groups with 20-30 specimens in each are stored, which total approximately 15000 plants. The collection represents diversity patterns in populations (mostly narrow-leaved fescue species) in various geographical areas and allows analyzing the peculiarities of species differentiation anatomically and morphologically in different ecological conditions, in natural and anthropogenically disturbed habitats, in cultivation, and even under weather and climatic changes in different years.

Keywords: Festuca, herbarium collection, population

In the course of our critical revision of taxonomy of the genus Festuca in the flora of western regions of Ukraine (Bednarska, 2007), based mainly on the herbarium of the Institute of Ecology of the Carpathians, National Academy of Sciences of Ukraine (LWKS), a specialized herbarium collection of species of Festuca was established in 1995. During 23 years of the collection's lifetime, geography of collections and diversity of species represented in it significantly extended, and the collection itself has became a unique assemblage in many aspects, in particular, in view of methodological basis of its formation.

The main peculiarity of author's approach and its distinction from other works in taxonomy of Festuca is the main attention paid to natural populations as main research units. Correspondingly, collecting of research material, its processing and storage in herbaria were implemented on the population-based approach (Bednarska, 2003), while the main unit of herbarium storage is a population sample group that usually consists of ca. 20-30 plant specimens.

Among the greatest challenges in studying critical taxa is the usually geographically patchy study of species in different parts of their worldwide ranges, when the main attention is attracted to particular selected taxa only; that often results in impossibility to compare data obtained by different authors using diverse approaches (Bednarska, 2013).

Many contemporary authors underestimate the fact that the results obtained by them depend mainly on the origin and amount of their studied material. Already 50 years ago, M. Bidault (1968) emphasized this problem. Among key basics of work with taxa of narrow-leaved Festuca M. Bidault mentioned that (1) collecting of material should be performed within particular (specific) plant associations and (2) quantity of samples should amount to at least 10-20 plants (in footnote the Bodault mentioned that, for more reliable results, it is better to study 50-100 specimens, although that would slow down the work and reduce the number of studied taxa). «Thus, these 20 plants are specimen statistically and population biologically ... we insist on this point of view, inasmuch as it is really fundamental for continuing our research (Bidault, 1968: 225)».

Bednarska I., 2018 
However, taxonomists still apply for taxonomic studies mostly available specimens accumulated in herbaria, avoiding troubles of making special collections. Our comparison of the number of publications by outstanding experts in the genus, both by origin and numbers of the studied plant specimens, proves that in the majority of these publications, nothing else but material from herbaria was used for studies of taxonomy of the genus (meaning only scattered collections made by different collectors from different areas and at different time). Certainly, they should be treated - it is one of basic requirements to such type of works; however, when studying critical taxonomic groups, only the population-based approach, and only sample groups representative enough, should serve as the main units of research. Key principles of population sample groups collection for the genus Festuca species were highlighted in one of our previous publications (Bednarska, 2003).

Totally, as of April 2018, the population collections in the LWKS herbarium contain more than 600 sample groups, comprising approximately 15 thousand of individual plants. Geographically, 8 administrative regions (oblasts) in the western regions of Ukraine are best represented in the collection; these regions were best covered by field surveys and research of the author. In addition to the mentioned areas, expeditions to Kyiv (10 sample groups), Zhytomyr (29 sample groups), Sumy (8 sample groups), Luhansk (7 sample groups), Donetsk (10 sample groups), Kharkiv (33 sample groups), Odesa, and Mykolaiv administrative regions (29 sample groups) and to Crimea (14 sample groups) resulted in rather large representation of local populations.

Materials from the Republic of Belarus collected in the course of a monographic taxonomic treatment of the genus Festuca in that country also worth special mention. Totally, 36 sample groups represent diversity patterns of the genus in the flora of Belarus.

Approximately 72 populations represent the genus in the flora of Poland, and 22 populations were in the Baltic countries (Lithuania, Latvia, and Estonia). The work on these collections (to clarify some taxonomic issues in the group of narrow-leaved fescues) continues but it is still far from its completion, even concerning the territories where other monographers of the genus worked before (in particular, in Poland). That revision of the species composition from particular territories already resulted in revealing new forms/taxa occuring there, not so much due to newest molecular-genetic methods as due to the population approach to critical taxa, which allows interpreting their variation in nature more adequately.

Alongside collections demonstrating diversity pattern of the genus in various natural geographic regions, collection of sample groups is also of utmost importance. One of the key issues in taxonomy of the genus is the problem of the variation amplitude of diagnostic characters, the factors influencing those patterns and norms of reactions in particular species. Such factors include (but are not limited to) weather conditions, annual variation, modification effects of the environment on morphology and anatomy of plants in populations, etc. To give answers to these questions, experimental plots were arranged by the author in the territory of Rohatyn Opillia (Ivano-Frankivsk Oblast), where repeated samplings of local populations for the $F$. valesiaca aggregate were observed already for four years. Approximately 40 sample groups, which now are kept at the Institute, enabled us to reveal certain regularities in dynamics of characters for these species and to make sometimes quite unexpected conclusions (Bednarska, 2014). Furthermore, to answer the abovementioned questions and to perform comparative analysis of changes in parameters of natural populations in cultivation conditions, an experimental research plot was arranged in Lviv city; 8 sample groups (also collected throughout four years) represent the corresponding changes.

Herbarium collections of Festuca also comprise samples representing different age stages of some rare species, in particular, F. heterophylla Lam., F. pallens Host, and F. psammophila (Hack. Ex Celak) Fritsch, collected in the course of studying their ontomorphogenesis and 
peculiarities of generative (true) reproduction (including analysis of potential and actual seed productivity).

Many population collections were gathered for comparative analysis of species in natural and anthropogenically modified habitats, and for analysis of adaptation capabilities of species under changed environmental conditions (natural outcrops and pits, recreational areas, landfills, fallows, ecotones in man-made woodland belts, etc.).

Especially important are collection made from sites of original descriptions of taxa (loci classici), which may serve as baselines for further comparative analysis. Among such taxa sampled in their loci classici are five species described from the territory of Ukraine: F. polesica Zapał. (Rivne Oblast), F. arietina Klok. (Kharkiv Oblast), F. taurica Hack. (Mykolaiv Oblast), Festuca rubra subsp. cretacea Lavr. (Luhansk Oblast), F. callieri (Hack. ex St.-Yves) Markgr. (Crimea). Certainly, population sample groups and type specimens (holotypes) of the species described by the author, including $F$. x polovina Bednarska, F. galiciensis Bednarska (Bednarska, 2017), F. hypanica Bednarska (nom. provis.), and some other species still awaiting taxonomic clarification, are represented in the collection as well.

It should be mentioned that the absolute majority of the genus collections is represented by narrow-leaved fescues (Festuca subg. Festuca), which belong to critical taxonomic groups. As to the remaining species of the genus identification of which is not very complicated, in particular, broad-leaved fescues (Festuca subg. Schedonorus, now often placed in Lolium sensu lato) and Carpathian endemics (subg. Drymanthele), they are represented by mainly sporadic collections, which essentially specify chorologic data on these species.

As we see, functions of herbarium collection as an archive of scientific research are very broad. Apart from directly representing diversity patterns of species in a particular region, revision of some author's hypotheses is impossible without such collections.

Unfortunately, we are not aware of any other collections similar to our collection in their scope, coverage, and research goals. That slows down the work, since we have to conduct comparative analysis of species of the genus based solely on our own collections, made by unified principles and with taking into account factors that may influence differentiation patterns of populations. Study of taxonomy of Festuca in the flora of Ukraine and adjacent countries continues, and new species and specimens from both previously sampled and unsampled territories are added to our collection every year. Other researchers are invited to contribute to our Festuca collection in Lviv. Of course, collecting at least 25 specimens per population in compliance with the strict requirements mentioned above is a challenge; nevertheless, we hope that other botanists, after having read this article, would like to participate in adding to LWKS new specimens of Festuca from various populations.

\section{REFERENCES}

1. Bednarska I. Recommendations on gathering of genus Festuca (Poaceae) species to herbarium collection // Visnyk Luhanskogo derzh. ped. universytetu im. T. Shevchenka. 2003. № 11 (67). P. 62-64. (In Ukrainian).

2. Bednarska I. The genus Festuca L. (Poaceae) in the flora of Western Ukraine. 2007. PhD Thesis. M.G. Kholodny Institute of Botany, National Academy of Sciences of Ukraine, Kyiv (In Ukrainian).

3. Bednarska I. Geographical and temporal variation of anatomical and morphological parameters in the populations of Festuca valesiaca agg. (Poaceae) in the flora of the Rohatyn Opilla 
region (Ukraine) // Scientific Principles of Biodiversity Conservation. 2014. Vol. 5(12). № 1. P. 31-58. (In Ukrainian).

4. Bednarska I., Brazauskas G. Festuca galiciensis, a new species of the $F$. valesiaca group (Poaceae) from Ukraine // Phytotaxa. 2017. 306(1). P. 21-36.

5. Bidault M. Essai de taxonomie expérimentale et numérique sur Festuca ovina L. s. 1. dans le sud-est de la France // Rev. Cytol. et Biol. Vég. 1968. 31. P. 217-356.

\title{
ПРО ГЕРБАРНУ КОЛЕКЦІЮ ПОПУЛЯЦЙ РОДУ FESTUCA L. (POACEAE) (LWKS)
}

\section{I. Беднарська}

\author{
Інститут екології Карпат НАН України \\ вул. Козельницька, 4, Львів 79026, Украӥна \\ e-mail:Ibednarska@ukr.net
}

Під час монографічного опрацювання систематики роду Festuca у флорі Центральної Європи, на базі LWKS було сформовано спеціалізовану гербарну колекцію роду. Ключовою особливістю колекції є популяційні засади збору матеріалу. На сьогодні у фондах зберігається близько 600 популяційних вибірок по 20-30 зразків у кожній, які загалом налічують близько 15000 рослин. Колекція представляє різноманітність популяцій (переважно вузьколистих видів костриць) у різних природногеографічних регіонах і дає змогу аналізувати особливості анатомічної та морфологічної диференціації видів у різних екологічних умовах, у природних і антропогенно порушених біотопах, в умовах культури та за погодно-кліматичних змін у різні роки.

Ключові слова: Festuca, гербарна колекція, популяції 